\title{
A Rare Complication of Tinea Capitis: Urticarial Id Reaction
}

\section{Tinea Kapitisin Nadir Bir Komplikasyonu: Ürtikeryal İd Reaksiyonu}

\author{
Okan Kızılyel', Ömer Faruk Elmas', Mustafa Görgün², Mahmut Sami Metin³, Fatma Doğan \\ 'Department of Skin and Venereal Diseases, Ataturk University School of Medicine, Erzurum, Turkey \\ ${ }^{2}$ Department of Family Medicine, Ataturk University School of Medicine, Erzurum, Turkey \\ ${ }^{3}$ Clinic of Dermatology, Afsin State Hospital, Kahramanmaras, Turkey \\ ${ }^{4}$ Clinic of Family Medicine, Ceylanoglu Family Health Center, Erzurum, Turkey
}

\section{Abstract}

Tinea capitis that usually affects prepubertal age group of children is a dermatophyte causes superficial fungal infection of hair follicle and follicle surroundings. Id reaction is a rare condition and considered to be a delayed hypersensitivity reaction opposed to dermatophyte antigens. It is usually seen as papular and vesicular morphologies. Urticarial id reaction is extremely rare. In here, we have reported two cases of urticarial id reaction caused by tinea capitis profunda and we pointed out that tinea capitis may be an etiological factor of urticarial reactions. We have presented this case because the clinical entity is extremely rare.

Keywords: Dermatophyte, id reaction, tinea capitis profunda, urticaria

\section{Introduction}

Tinea capitis (TC) is a dermatophyte-induced superficial fungal infection of the hair follicle and follicular surrounding. Clinical picture: three clinical forms have been described, including tinea capitis superficialis (TS), tinea capitis profunda (TP) and tinea capitis favosa (TF) (1). The etiologic agents of TC are dermatophytes which belong to the Trichophyton and Microsporum family. TP was first discovered by Celsus in the year $30 \mathrm{BC}$, and was defined as an acute purulent inflammatory
Özet

Sıklıkla prepubertal yaş grubundaki çocukları etkileyen tinea kapitis; saç folikülü ve folikül çevresinin dermatofit kaynaklı yüzeyel fungal enfeksiyonu olarak tanımlanabilir. Dermatofitoz tanılı hastalarda nadir görülen id reaksiyonu; dermatofit antijenlerine karşı gelişen gecikmiş tipte hipersensitivite reaksiyonu olarak kabul edilmektedir. İd reaksiyonu, sıklıkla papüler ve veziküler morfolojide izlenir. Ürtikeryal id reaksiyonu ise oldukça nadirdir. Bu makalede, tinea kapitis profundaya bağlı gelişen, ürtikeryal id reaksiyonu tanısı konulan iki pediatrik olgu sunulmuş ve tinea kapitisin, ürtikeryal reaksiyonların olası bir etyolojik faktörü olabileceği vurgulanmıştır. Olgularımızı, tablonun oldukça nadir görülmesi nedeniyle sunuyoruz.

Anahtar Kelimeler: Dermatofit, id reaksiyonu, tinea kapitis profunda, ürtiker

condition of the hairy scalp, involving a distinct inflammatory process when compared to the other forms of TC (2). Clinically, fever, lymphadenopathy and leukocytosis may be observed in cases with TP, which is characterized by inflammatory, sensitive, multiple alopecic nodular and pustular lesions (3-5).

\section{Case Reports}

\section{Case 1}

A five-year-old boy presented with multiple alopecic nodular and pustular lesions with itchy and painful scalp lesions 
for about 1.5 months (Figure 1). In the last two weeks, localized urticarial papules and plaques on the torso and limbs were added to the clinical picture (Figure 2). No particular abnormalities were observed on physical examination of the patient apart from the moderate high fever (axillary $38.2^{\circ} \mathrm{C}$ ). Neutrophilic leukocytosis (leukocyte $15.800 / \mu \mathrm{L}$, neutrophil $13.700 / \mu \mathrm{L}$ ) was detected in the laboratory analysis. Routine biochemistry, urogram, thyroid function tests and vaginal parasitology tests were within normal limits. Fungal hyphae structures were detected on direct microscopic examination after treatment with $\mathrm{KOH}$ on material obtained from pustular lesion. Patients who were diagnosed with TP using current clinical and laboratory findings were given 125 mg/day terbinafine (orally) for six weeks, $10 \mathrm{mg} /$ day prednisolone (orally) for seven days, $6 \mathrm{mg} / \mathrm{kg} /$ day cotrimoxazole suspension for two weeks, $20 \mathrm{mg} / \mathrm{kg} /$ day ibuprofen suspension and local antiseptic treatment for four weeks. During the first week of treatment, the urticarial papules and plaques of the patient were found to have completely regressed, while fungal lesions on the scalp were observed to have almost recovered by the tenth week of treatment.

\section{Case 2}

An 11-year-old boy was admitted with localized sporadic pustules, erythematous, squamous plaque-like skin lesions in the left temporal region, approximately $4 \times 6 \mathrm{~cm}$ in diameter (Figure 3). The patient's complaints had been present for approximately one month and widespread urticarial papules and plaques had developed throughout the body over the

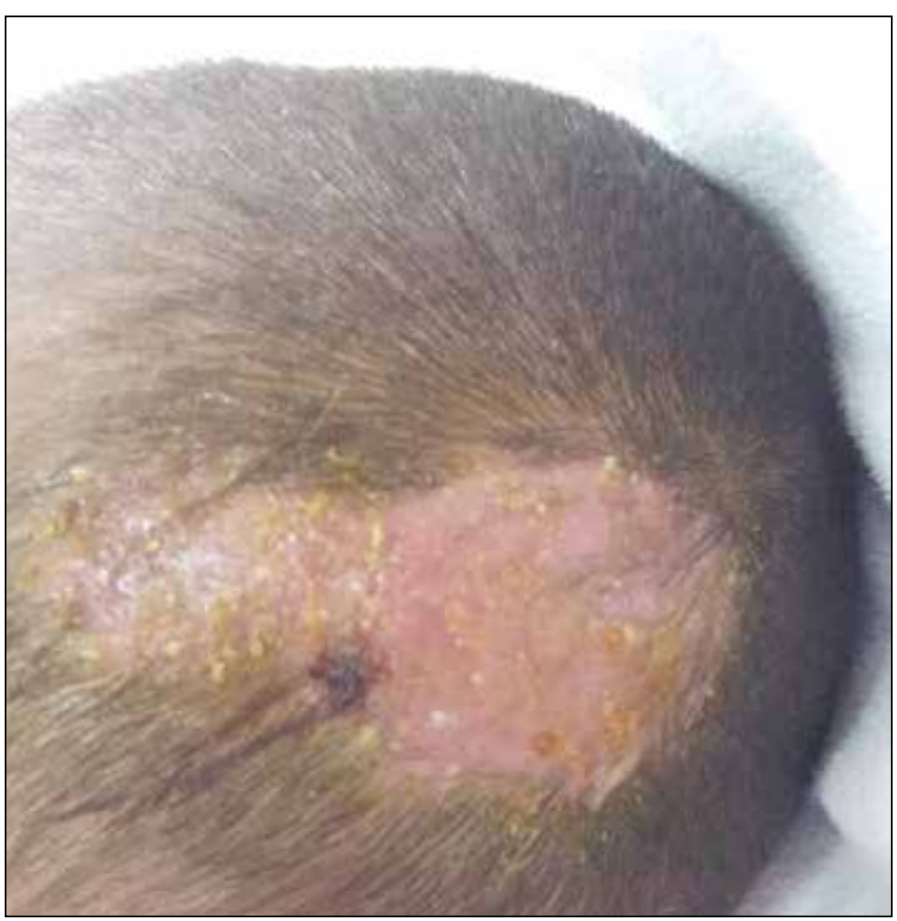

Figure 1. Alopecic nodular and pustular lesions on hairy scalp.

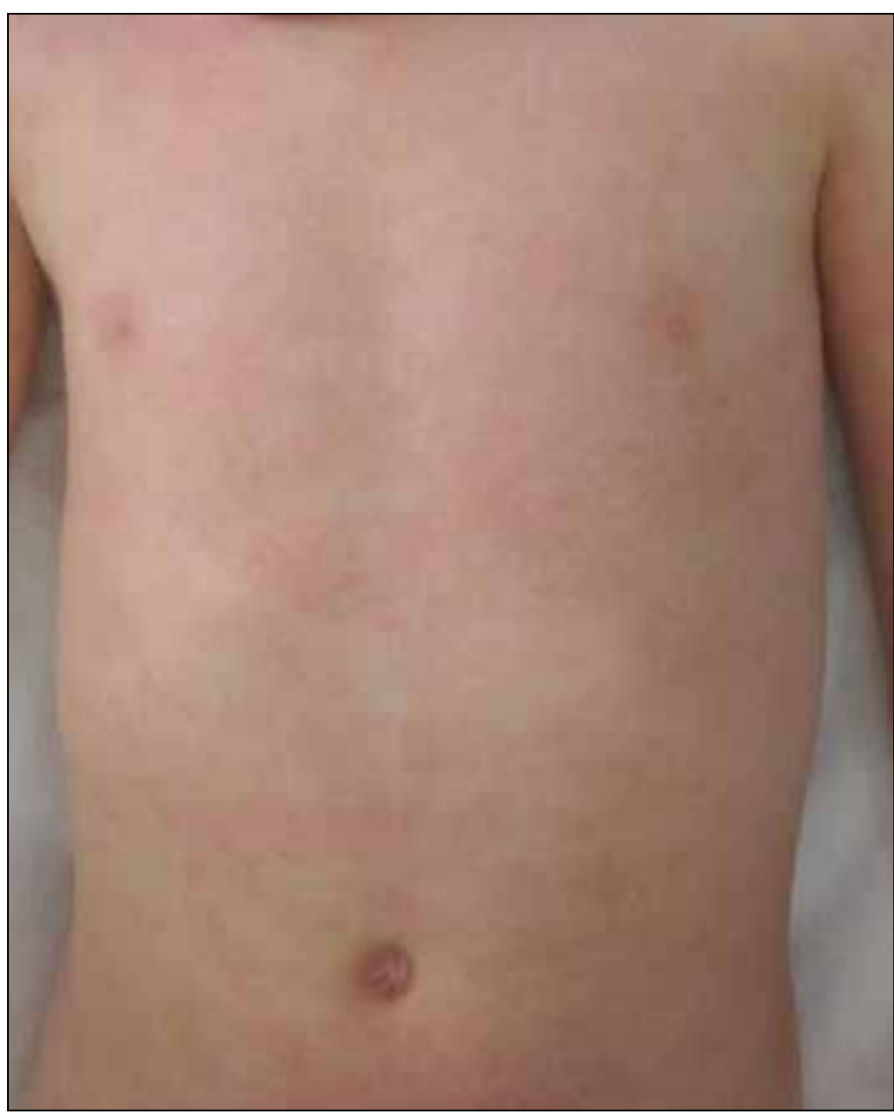

Figure 2. A large number of urticarial papules and plaques of different diameters on the anterior torso.

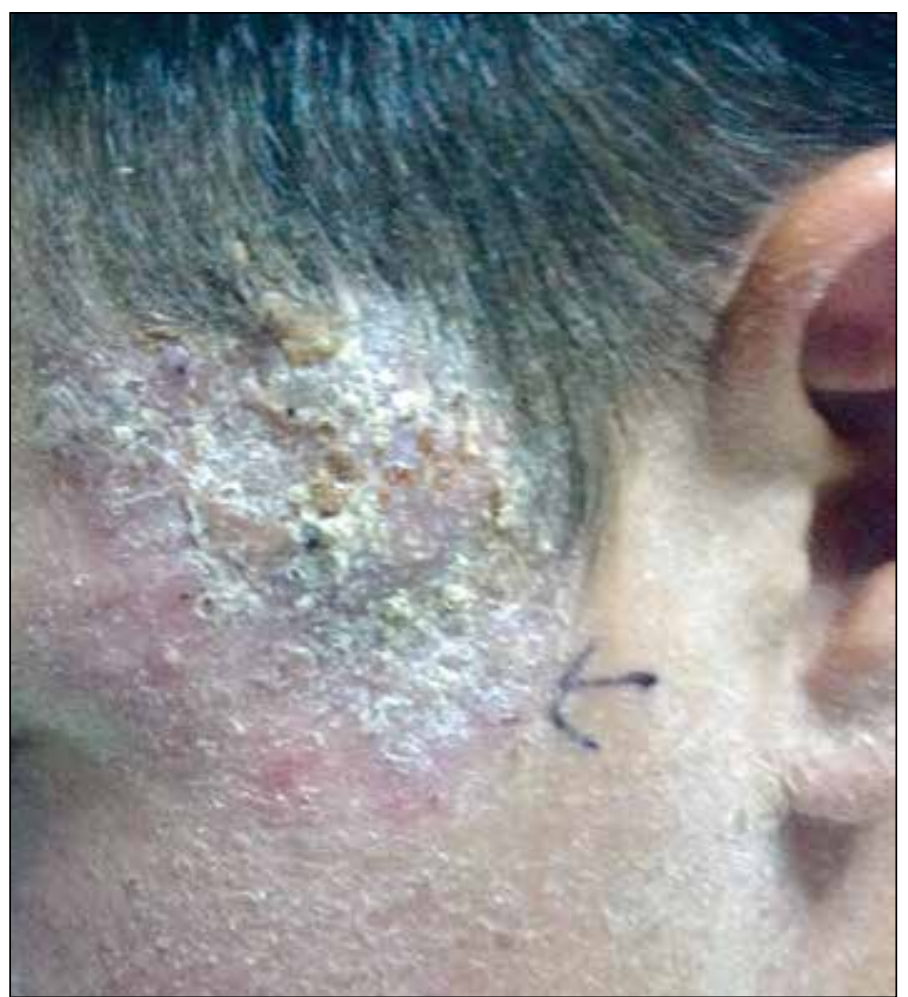

Figure 3. Plaque-like lesion in the temporal area with erythematoussquamous sporadic pustules. 


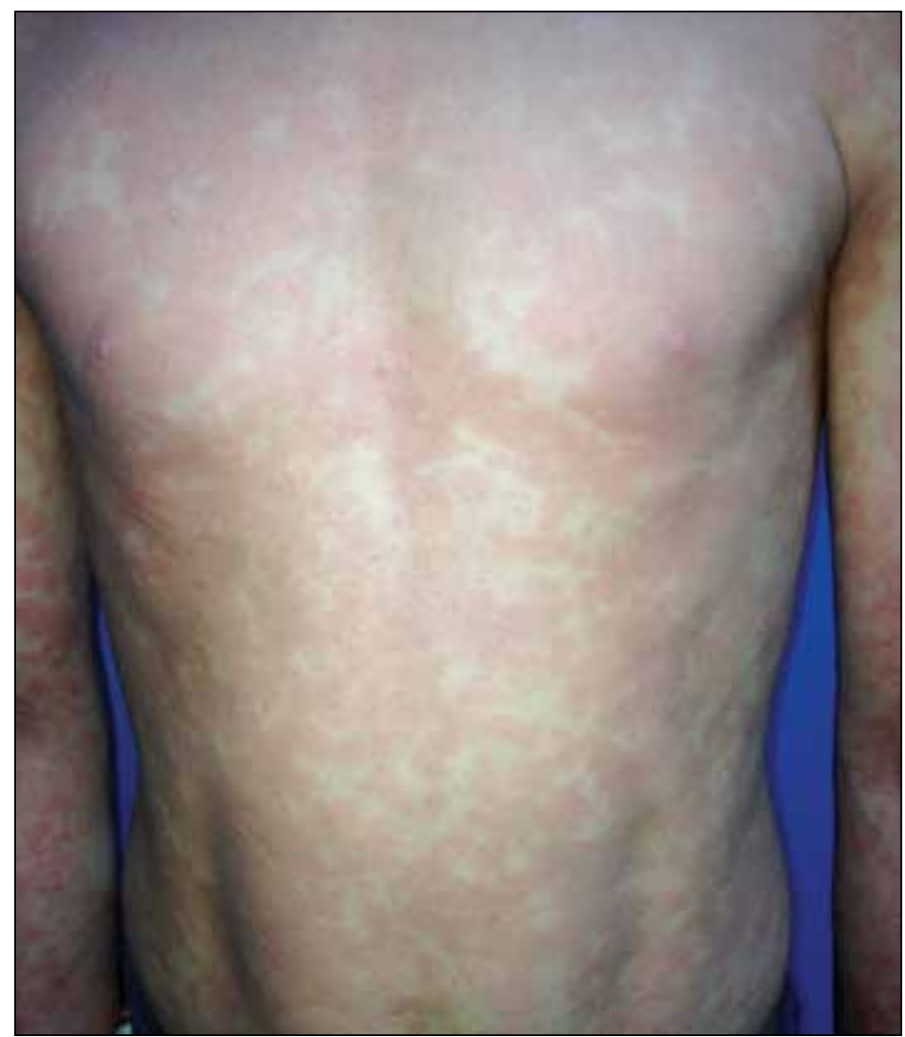

Figure 4. Widespread urticaria on the torso and extremities.

last three days (Figure 4). No abnormal features were observed in the patient's systemic physical examination. Laboratory analysis did not reveal any additional findings other than mild neutrophilic leukocytosis. Fungal elements were detected in a direct microscopic examination after the treatment of the squamous material taken from the active erythematous margins of the temporal lesion with $\mathrm{KOH}$. In our present case, which was evaluated as TP, the treatment protocol indicated in our first case was initiated at an appropriate dose. On the third day of treatment, complete recovery was observed in the urticarial lesions. On the other hand, the clinical picture of TP showed near complete improvement by the end of the fourth week.

\section{Discussion}

Dermatophytic infection of the hairy scalp is usually observed in preadolescent children. Patients present with severe inflammatory alopecic nodular lesions and malodorous discharge, often accompanied by pustular lesions, although the clinical course differs. Cicatricial alopecia is often inevitable when the clinical condition remains untreated or when there is a delay in treatment (6). Our two cases were both consistent with the age group and clinical appearance as described in literature studies. In cases with TP, also known as Kerion Celsi, regional lymphadenopathy, fever and various interface dermatitis (Id) reactions can be observed. The prevalence of Id re- actions in dermatophyte-derived superficial fungal infections is approximately $5 \%$ (7). An Id reaction is considered to be a delayed type hypersensitivity reaction against dermatophyte antigens. In the etiopathogenesis, the fungal antigens have been deemed responsible by patient antibodies for opsonization and cytokines secreted by sensitized T-helper cells (8). Id reactions may present as a broad spectrum of dermatological lesions. Some criteria have been defined for the identification of the reaction. These criteria include, the mycologically proven fungal infection focus, the fact that the lesion defined as an Id reaction is not flanked by the fungal infection focus, the absence of a fungal agent in the lesion considered to be an Id reaction, and the spontaneous regression of the Id reaction when the fungal infection is treated (9). In both of our cases, fungal hyphae structures were detected on direct microscopic examination (native preparation method) and the urticarial plaques were found to have rapidly regressed after treatment. The classic Id reactions observed in TC are papular and vesicular lesions that develop on the face and the torso. Id reactions can rarely be seen in the morphology of urticaria, follicules, papules, erythema multiforme, erythema annulare centrifugum, and erythema nodosum (10). Atzori et al. presented a 37-year-old male patient with erythema multiforme-like Id reaction that developed on the distal portion of the extremity due to tinea infection on the nose (11). Castriota et al. reported an erythema nodosum-like Id reaction in the lower extremity of a nine-year-old girl diagnosed with TP and stated that the clinical findings were relieved by antifungal therapy (12). Zaraa et al. also presented a 7-year-old male patient with erythema nodosum associated with TP (13). The majority of lesions identified in literature studies as Id reactions have the morphology of papules, vesicules, erythema nodosum and erythema multiforme; however, unlike the classic Id reaction patterns, urticarial lesions were remarkable in our patients.

\section{Conclusion}

In conclusion, it is not always possible to identify the agent that causes the urticarial lesions. Drug allergic reactions can clinically be difficult to differentiate from urticarial Id reaction. Patients who present with urticarial lesions and whose etiology is not clear should be considered for a clinical picture of Id reaction and patients should be carefully examined for superficial fungal infections.

Informed Consent: Written informed consent was obtained from the patient and parents of the patient.

Peer-review: Externally peer-reviewed.

Author Contributions: Concept - OK; Design - ÖFE; Supervision MG; Data Collection and/or Processing - MSM; Literature Review - FD; Writing - OK; Critical Review - ÖFE, MSM; all authors contributed to patient follow-up. 
Conflict of Interest: The authors have not reported a conflict of interest.

Financial Disclosure: The authors declared that they did not receive financial support.

\section{References}

1. Elewski B. Tinea capitis. Dermatol Clin 1996;14:23-31. [CrossRef]

2. Rosenthal T. Aulus cornelius celsus. Arch Dermatol 1961;84:613-8.

3. Elewski BE. Tinea capitis: a current perspective. J Am Acad Dermatol 2000;42:1-20. [CrossRef]

4. Ilkit $M$, Demirhindi $H$. Asymptomatic dermatophyte scalp carriage: laboratory diagnosis, epidemiology and management. Mycopathologia 2008;165:61-71. [CrossRef]

5. Fuller LC, Child FJ, Midgley G, Higgins EM. Diagnosis and management of scalp ringworm. BMJ 2003;326:539-41. [CrossRef]

6. Freedberg $I M$, Eisen $A Z$, Wolff $K$ (eds). Fitzpatrick's dermatology in general medicine. 6th ed. Vol 2. 2003:2201-4. [CrossRef]

7. Gianni $C$, Betti $R$, Crosti C. Psoriasiform id reaction in tinea corporis. Mycoses 1996;39:307-8. [CrossRef]
8. Mark BJ, Slavin RG. Allergic contact dermatitis. Med Clin North Am 2006;90:169-85. [CrossRef]

9. Cheng N, Rucker Wright D, Cohen BA. Dermatophytid in tinea capitis: rarely reported common phenomenon with clinical implications. Pediatrics 2011;128:e453-7. [CrossRef]

10. Bassi N, Kersey P. Erythema nodosum complicating a case ofkerion celsi of the scalp due to Tricophyton mentagrophytes. Clin Exp Dermatol 2009;34:621-2. [CrossRef]

11. Atzori L, Pau M, Aste M. J Eur Acad Dermatol Venereol 2003;17:699-701. [CrossRef]

12. Castriota M, Ricci F, Paradisi A, et al. Erythema nodosum induced by kerion celsi of the scalp in a child: a case report and mini review of literature. Mycoses 2013;56:200-3. [CrossRef]

13. Zaraa I, Trojjet S, El Guellali N, et al. Childhood erythema nodosum associated with kerion celsi: a case report and review of literature. Pediatric Dermatol 2012:4;479-82. [CrossRef] 